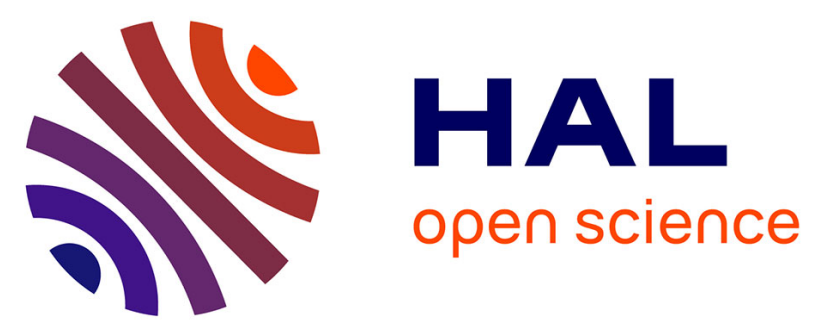

\title{
Corrigendum to "Measuring liquid meniscus velocity to determine size of nanopipette aperture" [J. Colloid Interface Sci. 392 (2013) 465-469]
}

Evelyne Salançon, Bernard Tinland

\section{- To cite this version:}

Evelyne Salançon, Bernard Tinland. Corrigendum to "Measuring liquid meniscus velocity to determine size of nanopipette aperture" [J. Colloid Interface Sci. 392 (2013) 465-469]. Journal of Colloid and Interface Science, 2018, 526, pp.505. 10.1016/j.jcis.2018.05.047 . hal-01957990

\author{
HAL Id: hal-01957990 \\ https://hal.science/hal-01957990
}

Submitted on 31 Jan 2019

HAL is a multi-disciplinary open access archive for the deposit and dissemination of scientific research documents, whether they are published or not. The documents may come from teaching and research institutions in France or abroad, or from public or private research centers.
L'archive ouverte pluridisciplinaire $\mathbf{H A L}$, est destinée au dépôt et à la diffusion de documents scientifiques de niveau recherche, publiés ou non, émanant des établissements d'enseignement et de recherche français ou étrangers, des laboratoires publics ou privés. 


\section{Journal of Colloid and Interface Science}

\section{Corrigendum}

Corrigendum to "Measuring liquid meniscus velocity to determine size of nanopipette aperture” [J. Colloid Interface Sci. 392 (2013) 465-469]

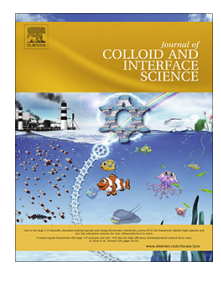

Evelyne Salançon, Bernard Tinland*

Aix Marseille Université, CNRS, CINaM UMR 7325, 13288 Marseille, France

The authors regret that it is written:

$Q=\frac{\pi}{4} a^{2} v$ instead of $Q=\pi a^{2} v$

$b=12.43 \sqrt[3]{\frac{a v l}{\Delta P}}(3)$ instead of $b=0.1243 \sqrt[3]{\frac{a v l}{\Delta P}}(3)$

And $b=12.43 \sqrt[3]{\frac{a^{2} v\left(L-L_{c}\right)}{c \cdot \Delta P}}(4)$ instead of $b=0.1243 \sqrt[3]{\frac{a^{2} v\left(L-L_{c}\right)}{c \cdot \Delta P}}(4)$

The authors would like to apologise for any inconvenience caused.

DOI of original article: https://doi.org/10.1016/j.jcis.2012.10.044

* Corresponding author.

E-mail address: tinland@cinam.univ-mrs.fr (B. Tinland). 